\title{
How American Media Affects Perceived Racism in Canada
}

\author{
Emily Morgan Wiebe*
}

\begin{abstract}
This study aims to identify how perceptions of racism in Canada are influenced by the consumption of American media. The current study hypothesized that: 1 ) individuals exposed to an American news story regarding racial discrimination (Group 1 ) would have a more favourable evaluation of Canada than those who were not exposed to the story (Group 2); 2) that participants who were people of colour ( $\mathrm{PoC}$ ) would have no significant differences in scores between the two groups, and; 3) that Canadians would overall rate Canada more favourably than America, but that this difference would be more pronounced in Group 1. Seventy-two (72) participants contributed data by completing one of two versions of a questionnaire, which had questions regarding satisfaction of one's life in Canada, perceived ethnic diversity or acceptance in Canada, perceived racism in Canada, and a comparison between Canada and the USA. One version opened with a short vignette describing an example of racism that had recently occurred in America (Group 1; 47 questions), while the other version did not (Group 2; 46 questions). A $2 \times 2 \times 2$ analysis of the data revealed that PoC and those with a different national affiliation exhibited lower scores of perceived diversity in Group 1 than Group 2. Caucasian participants evaluated Canada more favourably than America in Group 1, whereas PoC rated Canada better in Group 2. Limitations of this study included sample size, diversity of the sample, reliability of the scales, and self-selection/self-report biases. Future research should aim to rectify these limitations and further explore the significant differences present in this study.
\end{abstract}

Keywords: racism, Canada, America, media, diversity, PoC

\section{Introduction}

Categorizing individuals based on certain characteristics is a phenomenon that stems from the need to identify the group to which one belongs and trusts. This adaptive strategy forms the basis for discrimination of others based on physical appearance, language, national affiliation, or religious and political beliefs. Physical markers are believed to indicate status, intelligence, and general worth as a human being (Wendt, 2009). Although racial equality has progressed immensely, comparisons to past or present societies deemed less progressive may create an illusion of a non-racist society (Gulliver, 2017). The literature argues that relatively recently, Canada has fallen victim to this thought process (Gulliver, 2017; Waters, 2015; Wendt, 2009), though Evelyn Kallen has pointed out:

While discrimination... had definitely not disappeared in Canada. What has happened is that blatant racism has gone 'into the closet', where it has

*Department of Psychology, College of Arts \& Science, University of Saskatchewan, Saskatoon, SK, Canada

Correspondence: emw981@mail.usask.ca

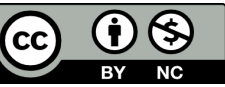

University of Saskatchewan Undergraduate Research Journal Volume 6, Issue 2, 2020

() 2020 Emily Wiebe. This open access article is distributed under a Creative Commons Attribution Non-commercial 4.0 license. (https://creativecommons.org/licenses/by-nc/4.0/) 
transformed into its more subtle, 'polite' counterpart... (Waters, 2015, p. 10).

In this study, race is based on Pierre van den Berghe's definition: people that are classified by themselves and/or others as unique from other groups due to natural physical characteristics which are connected to inherent characteristics and abilities (Wendt, 2009). Accordingly, racism is then:

\begin{abstract}
any set of beliefs that organic, genetically transmitted differences (whether real or imagined) between human groups are intrinsically associated with the presence or absence of certain socially relevant abilities or characteristics, hence that such differences are a legitimate basis of invidious distinctions between groups socially defined as races (Wendt, 2009, p. 476).
\end{abstract}

However, in defining racism this way, it is important to bear in mind that differences among groups in terms of social achievement or success are often a result of cultural ideas about biogenetic differences, not actual biological differences (Wendt, 2009). Racism also differs largely in type, and often there is a specification between "new" racism (covert) and "old" racism (overt) as well as between racist attitudes (beliefs) and racist actions (discrimination) (Atkins, 2014; Vala, 2009). Vala (2009) proposes that all forms of racism are reinforced by political, economic, and historical backgrounds in a national context. The circumstances racism is imbedded in contribute to a recent understanding that overt racism is inappropriate but perpetuating racist ideologies through hidden methods is suitable. By studying the continuous adaptation of racism throughout history, we can see that racism is a ubiquitous, powerful force despite disparities in expression.

\section{Literature and Theory}

Social identity theory has been a popular theory in social psychology since the 1970 (Higgins, Krunglanski, \& Van Lange, 2011). It is important to note that social identity itself is defined as, "that part of an individual's self-concept which derives from [their] knowledge of [their] membership in a social group (or groups) together with the... emotional significance attached to that membership" (Tajfel, 1978, p. 63). Therefore, social identity theory proposes that group membership leads individuals to view their group more favourably and see other groups as less desirable or inferior (Armstrong, Dovidio, Esses, \& Jackson, 2001; Brown, Klink \& Mummendey, 2001; Druckman, 1994). The purpose of the theory is to help understand and explain why individuals adopt social identities and behave accordingly as opposed to depending on personal identities (Higgins, Krunglanski, \& Van Lange, 2011). Previous research on the topic has shown that the answer lies in an individual's self-esteem. According to Druckman (1994), viewing one's group in positive terms increases individual self-regard, which is further boosted when one makes a favourable comparison between the group to which they belong and a different group. Therefore, the ability to discriminate and differentiate groups is a crucial component to increasing group loyalty, and subsequently, self-esteem (Druckman, 1994).

Self-categorization theory also directly contributes to in-group bias by focusing on the categorization that occurs when individuals identify with a particular group (Druckman, 1994). More specifically, it examines how one's self-concept changes based on perceived differences from others in a particular social context (Bentley, Greenaway, \& Haslam, 2017). Selfcategorization theory proposes that the sense of self changes with the environment and is defined according to context (Bentley, Greenaway \& Haslam, 2017). Two elements combine to create this phenomenon: perceptual accentuation and positive regard for in-group (Druckman, 1994). Perceptual accentuation occurs when people in the same category appear more similar to one another than people in differing or opposing categories (Druckman, 1994). Even individuals in highly similar groups will fixate on the differences between the two, usually by evaluating the opposing group more negatively (Druckman, 1994). Positive regard for in-group refers to the likelihood for individuals to view their group more positively than others, as proposed by social identity theory. This theory also relates to the cognitive self-reference effect, in which individuals show superior memory and recall of information pertaining to the self as opposed to information related to others (Bentley, Greenaway, \& Haslam, 2017). Therefore, more detail about the self is deeply encoded, contributing to the tendency for other groups to be perceived as more different, more negative, and based more on stereotypes than one's group (Bentley, Greenaway, \& Haslam, 2017).

America's and Canada's historical backgrounds are widely understood to differ in terms of race relations due to the tendency of historians to overlook Canada when studying segregation, slavery, or immigration-related issues (Wendt, 2009). As a result, Canadians have often claimed moral superiority over Americans due to the perceived confinement of racism to the United States (Gulliver, 2017; Wendt, 2009). However, as Boyko said, "Canadians are often guilty of ignoring or warping our past while sanctimoniously feeling somewhat removed from, and superior to, countries struggling with racial problems and harboring histories marked by slavery or racial violence" (Wendt, 2009, p. 478). In ignoring past laws and actions regarding racial inequality in Canada, one also ignores the similarities that existed in the 
past and are still relevant between American and Canadian culture. The resemblance between the two countries is likely due, in part, to geographical proximity, resulting in easy transmission of beliefs and practices, particularly from America to Canada (Waters, 2015). For example, slavery existed and was legally sanctioned in a number of British colonies, including New France, though not to the extent of the southern American slave trade due to the northern climate being inhospitable to the growth of materials like tobacco, cotton, or rice (Wendt, 2009). However, when former slaves from the USA started finding refuge in Canada and the black population started to grow, more discernable forms of racism started to appear, exemplified through the racial segregation that took place in the 1830 in several provinces, most notably Ontario and Nova Scotia (Waters, 2015; Wendt, 2009). Racial hierarchies were created and enforced in the legal systems of both America and Canada. Unlike America, "while anti-Black discrimination was not supported by positive law in Canada, throughout Canadian history the law tended to passively support white supremacy by accepting the conditions that allowed it to thrive" (Waters, 2015, p. 37). Racism and hostility against Chinese and Japanese immigrants also started to appear in both countries near the beginning of the $20^{\text {th }}$ century (Wendt, 2009). For example, Canada's Chinese Immigration Act barred Chinese citizens from entrance for 24 years, whereas the American Chinese Exclusion Act suspended immigrants for 10 years (Wendt, 2009). Segregated schools also influenced Japanese children in the early 1900s, and later Japanese families faced confiscation of their property and placement in internment camps in both Canada and America (Wendt, 2009).

Their similar pasts have shaped current racial environments in Canada and America. For example, both countries have immigration policies that ensure the economic success of immigrants, more so in Canada than America (Esses et al., 2001). In 2017, Canada allowed approximately 300,000 immigrants, 7,500 governmentfunded refugees, and 16,000 privately sponsored refugees into the country (Canadian Council for Refugees, 2018). The refugee count specifically was below the intended goal for 2017. America, however, accepted 1.13 million immigrants and 54,000 refugees, which was above the proposed quota (U.S. Department of Homeland Security, 2018). Though immigration statistics of both countries are vastly different, literature shows that prejudice against non-European residents in Canada and America remains relatively similar (Wendt, 2009).

As with the case of Michael Brown in Ferguson, Missouri (BBC News, 2015), Canada has also been chastised by the United Nations for allowing African Canadians to face harsher punishment by police and judicial officers in terms of arrests, stops, searches, releases, investigations, and incarcerations (United Nations, 2012). Moreover, there are disproportionately higher rates of Indigenous people in federal and provincial prisons and Indigenous women and girls who are victims of violence, homicide, and disappearances (United Nations, 2012). The Canadian government has yet to introduce specific punitive measures for acts of racial violence, allowing for the persistence of marginalization and stratification of Indigenous people and African Canadians (United Nations, 2012).

\section{The Current Study}

The relatively similar histories of Canada and America and their geographical adjacency, paired with the social identity theoretical framework and self-categorization theory, provided a sufficient background for the formulation of this study's hypotheses. The first hypothesis proposed that exposure to an American media story, including an example of racism, would cause participants to perceive life in Canada more favourably. Participants exposed to an example of racial discrimination in America would have higher scores regarding satisfaction with life in Canada, perceived acceptance/diversity, and perceived differences between Canada and America, and lower scores regarding the prevalence of racism in Canada than the other participants. The second hypothesis proposed that participants who were not Caucasian would have no significant differences in scores between the two groups across any of the previously mentioned categories. Finally, the last hypothesis of this study proposed that Canadian participants would score Canada better than America, and this difference would be more pronounced after reading the vignette about racism in America.

\section{Methodological Approach}

Both groups of participants were recruited through two online sources through the University of Saskatchewan ( $U$ of S): the Social Sciences Research Laboratories Research Participant Group (SSRL RPG) and through the $U$ of $S$ student portal, PAWS. Participants were given access to the study through links posted on the aforementioned websites and were randomly assigned to one of the two condition groups. The study was conducted using the Voxco online survey tool. The questionnaire opened with a page describing the study, potential harms and benefits of the survey to the participant, assurances that participants have the right to withdraw at any time, and that their answers will remain anonymous. After providing their informed consent, the participants then proceeded to either the vignette (Group 1) or the questionnaire (Group 2). The vignette described an example of racism that was prevalent in American news; it outlined a case of police brutality against a black man in which the perpetrator killed the victim and faced no punitive measures. The case took place in Ferguson, Missouri, in 2014, in which Michael Brown was fatally shot by police officer Darren Wilson (BBC News, 2015). This event 
faced public scrutiny and exposure in the months following Brown's passing (BBC News, 2015). The sequence of the subsections in the questionnaire, as well as the questions within each category, were randomized to combat potential order effects. The index was presented first, and the demographics last, to ensure that accuracy within the questionnaire was not sacrificed because of fatigue. Demographics included age, gender, location (country of birth, country where the most time has been spent, and country they consider home), amount of time spent in Canada, and ethnicity (Appendix A). Demographics for Group 1 also included a question regarding previous familiarity with the Michael Brown case. These items were collected to determine the diversity of the sample, what demographic characteristics were not represented, if any, and whether any significant differences in scores of variables of interest were related to demographic features. The debriefing page followed the demographic questions and explained the goals of the study in more detail to participants in addition to how the study would contribute to existing literature.

In the current study, two versions of the same questionnaire were used for all the participants, separating them into Group 1 (individuals reading the vignette) and Group 2 (individuals without a vignette). Individuals assigned to Group 1 were instructed to read the vignette carefully before moving on to the rest of the survey. Participants in Group 2 were not exposed to the vignette or any other American news stories, and instead were asked to complete the questionnaire immediately after consenting to participate in the study. The questionnaire was identical for Group 1 and Group 2 and asked participants to rate overall satisfaction with life in Canada; perceived racism in Canada in the individual, legal, and social domains; perceived ethnic diversity and acceptance of diverse ethnic groups; and a comparison between life in Canada and America and perceptions of racism in each (see Appendix A).

Following the data collection process, the data were analyzed using SPSS. In order to accurately gauge differences in scores on each subscale due to the outlined groups, ethnicity, national affiliation, or potentially all three variables, the researcher performed 2 [condition $(1,2)] \times 2$ [ethnicity (Caucasian, PoC)] x 2 [home country (Canada, elsewhere)] ANOVAs for each subscale with the scores on the subsections as the dependent variables to further investigate the results. In this instance, the null hypothesis predicted no significant differences between any of the groups.

\section{Results}

While 75 respondents participated in the study, 3 participants from Condition 1 were excluded from the analysis because they did not spend a sufficient amount of time ( $>30$ seconds) reading the vignette prior to completing the questionnaire, and therefore did not properly represent the effect that American media would have on responses ( $\mathrm{N}$ $=72$ ). Prior to the ANOVA, reliability testing revealed that the alpha levels for two of the subscales were very satisfactory [satisfaction $(\alpha=0.89)$, racism $(\alpha=0.88)$ ] whereas the other two subscales had adequate reliability [diversity $(\alpha=0.67)$, comparison $(\alpha=0.69)$ ]. When the descriptive statistics of each of the subscales were analyzed, scores on all measures showed normal distribution. The Levene's test for the ANOVAs showed that variances were equal across all samples [satisfaction $(F=0.694, p=0.667)$, diversity $(F=0.663, p=0.702)$, racism $(F=1.465, p=0.196)$, comparison $(F=1.049, p=0.407)$ ]. Since the dependent variables were continuous and all data were independent of each other due to the randomized nature of participant selection and the between-subjects design, all assumptions of a three-way ANOVA were met, and hypothesis testing could proceed.

The hypothesis that Group 1 would score higher on the satisfaction, diversity, and comparison subscales and lower on the racism subscale than Group 2 was the first to be tested. To analyze this, there would need to be a main effect of group on all four scales. However, this hypothesis was refuted as the satisfaction scale $[F(1,64)=1.676, p=0.200$, $\left.\eta_{p}{ }^{2}=0.026\right]$, diversity scale $\left[F(1,64)=2.916, p=0.093, \eta_{p}^{2}=\right.$ $0.044]$, racism scale $\left[F(1,64)=1.415, p=0.239, \eta_{p}{ }^{2}=0.022\right]$, and comparison scale $\left[F(1,64)=0.005, p=0.944, \eta_{p}{ }^{2}=0.000\right]$ had no main effects by group. Therefore, the data failed to support the first hypothesis.

The second hypothesis, that non-white participants would have no significant differences in scores between the groups, meant there would have to be an interaction between group and ethnicity on all four subscales. The satisfaction $\left[F(1,64)=3.208, p=0.78, \eta_{p}{ }^{2}=\right.$ $0.048]$ and racism $\left[F(1,64)=1.193, p=0.279, \eta_{p}{ }^{2}=0.018\right]$ subscales failed to demonstrate this expected outcome, as there was no interaction between ethnicity and group for either subscale. However, the diversity $[F(1,64)=4.040, p=$ $\left.0.049, \eta_{p}^{2}=0.059\right]$ and comparison $[F(1,64)=5.326, p=$ $0.024, \eta_{p}^{2}=0.077$ ] subscales both had statistically significant interactions between the participant's ethnicity and their group. For the comparison subscale, PoC scored much lower in Group $1(M=48.444$, $S D=7.939)$ than Group $2(M=52.167$, $S D=7.481$, whereas Caucasian participants scored higher in Group $1(M=50.913, S D=5.160)$ and lower in Group $2(M=$ 47.929, $S D=7.591$ ) (see Figure 1). For the diversity subscale, PoC who were in Group 1 rated diversity lower $(M=45.667$, $S D=7.906)$ than PoC in Group $2(M=53.917, S D=7.868)$. However, Caucasian participants scored diversity similarly in Group $1(M=46.522, S D=5.892)$ and Group $2(M=45.857$, $S D=6.127$ ) (see Figure 2). 
Figure 1: Interaction between condition and ethnicity on the comparison subscale for Canadian and non-Canadian participants. Caucasian participants displayed a preference for Canada in Group 1, the experimental group, as opposed to Group 2, the control group, whereas PoC demonstrated the opposite trend.

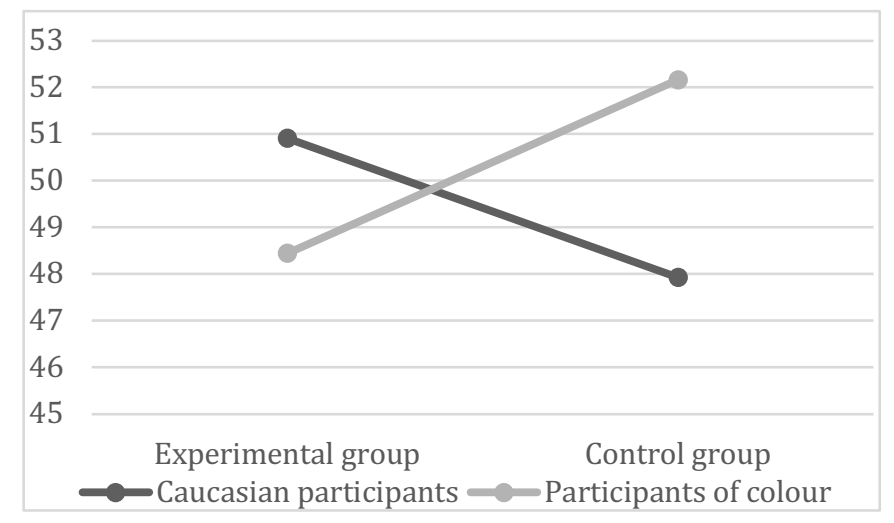

Figure 2: Interaction between condition and ethnicity on the diversity subscale for Canadian and non-Canadian participants. PoC perceived Canada to be less diverse after being exposed to the racially charged American news story, whereas Caucasian participants had no significant difference between groups.

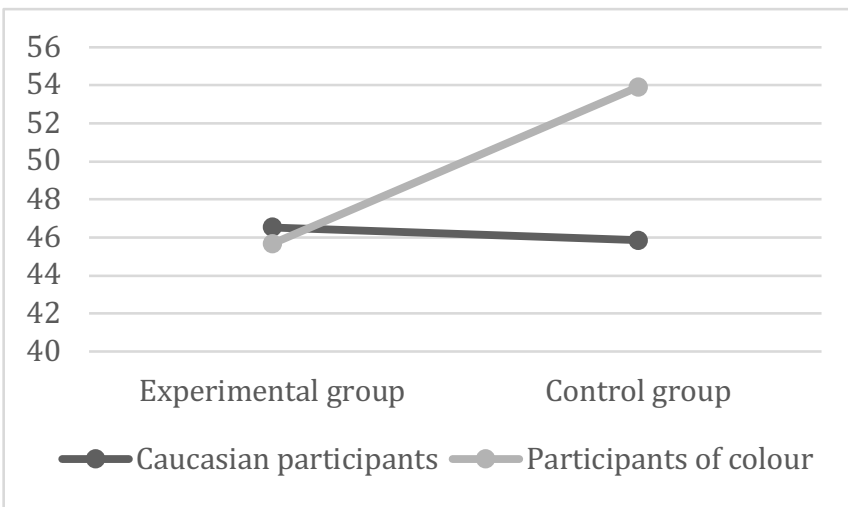

The third hypothesis proposed that Canadians would have higher comparison scores in both groups, but that score would be higher and there would be a more pronounced difference in Group 1. To explore this, there would have to be an interaction between national affiliation (home) and group on only the comparison subscale.

However, no such interaction was present $[F(1,64)=0.056$, $\left.p=0.814, \eta_{p}{ }^{2}=0.001\right]$. Therefore, the third hypothesis was also refuted.

An additional finding that was not predicted was an interaction between national affiliation and ethnicity on the diversity subscale. In addition to the interaction between ethnicity and group on this scale, there was also a prominent interaction between home country and ethnicity $[F(1,64)=$ 5.188, $\left.p=0.026, \eta_{p}^{2}=0.075\right]$. Descriptive statistics showed that PoC who identified Canada as their home scored lower for diversity $(M=47.750, S D=7.962)$ than PoC who identified with a different country $(M=58.800, S D=5.357)$. Similar to the previous interaction mentioned on the diversity subscale, Caucasian participants who identified with Canada $(M=46.109, S D=5.941)$ or a different country $(M=46.600$, $S D=6.950$ ) did not differ significantly on the diversity scale.

\section{Discussion}

The $2 \times 2 \times 2$ ANOVAs demonstrate that, overall, none of the hypotheses were supported. However, the second hypothesis that participants who were PoC would show no differences in scores between the conditions was actively refuted. Particularly for the diversity scale, PoC who identified Canada as their home country scored Canada lower in terms of ethnic diversity and acceptance, whereas PoC who identified home as a different country scored Canada higher in terms of perceived diversity. Caucasian participants, however, did not vary significantly in scores between groups, which counters the hypothesized results. These results demonstrated that $\mathrm{PoC}$, who potentially experience racism, are less likely to think Canada is accepting of racial variation when they either identify with Canada or when they are exposed to a racialized American news story. This result directly counters social identity theory and self-categorization theory by showing that group membership, if anything, decreased likelihood to view the in-group (in this case, Canada) in a positive way, and further contradicted the idea of perceptual accentuation (Brown, Klink, \& Mummendey, 2001; Druckman, 1994; Esses et al., 2001). However, this is likely explained by the experiences that PoC in Canada have faced, who may see Canada as being more similar to the USA in terms of racial discrimination than white individuals, who have not experienced racism first-hand. National affiliation with Canada as a PoC may result in taking a more critical look at Canada, versus those who consider themselves "outsiders," since those who identify with Canada have presumably spent more time in the country, and may therefore have more firsthand accounts of discrimination.

The interaction between ethnicity and group for the comparison between Canada and the USA partially supported one prediction. In this instance, Caucasian participants had higher scores than their non-white counterparts in Group 1, and then scored lower in Group 2. This finding supports social identity theory by showing more positive regard for the in-group (Canada) and a negative evaluation of the out-group (USA), but only when exposed to American media for Caucasian individuals (Brown, Klink, \& Mummendey, 2001; Druckman, 1994; Esses et al., 2001). PoC participants had the opposite response, displaying a more critical evaluation of Canada compared to America when exposed to American media, but a more lenient 
assessment when not exposed to the vignette. We partially predicted this outcome in that the Caucasian participants did evaluate Canada as superior to the USA in Group 1 on one subscale; however, it was not predicted that PoC participants would have the opposite reaction to the article. These results lead to the conclusion that PoC generally consider Canada and the USA to be more similar, whereas Caucasian people generally consider the two countries to be more different.

\section{Limitations}

Most of the significant limitations of this study are methodological flaws. As with any self-report method, the participant's ability to accurately report their feelings, traits, or experiences, influences the reliability of the index. If they are unable or unwilling to do so, the results become essentially meaningless. Future research in this field should attempt to control for this limitation by taking a mixed approach, perhaps by exposing participants to multiple televised news stories and asked questions regarding where they think the story originates in a laboratory setting. In addition to being a self-report survey, it was also based on self-selection of the respondents to participate, which means that those who did not participate in the survey may differ from the sample in a way that could potentially alter the results.

In addition to the method used, the questionnaire had flaws which may have affected the results of the study. The diversity and comparison subscales both had reliabilities below 0.7 , so both need to be revised in some way to increase the reliability, therefore increasing confidence in any significant results that are discovered using these forms of measurement. Specifically, the statements: "Most people living in Canada are not of European descent" from the diversity scale, and "The USA and Canada have similar laws in regards to handling hate crimes," were negatively correlated to more than 5 of the other items on their respective scales. By removing these questions and replacing them with ones that more accurately measure the variable that is being sought (in these cases, perceived ethnic diversity in Canada and perceived similarities between Canada and America), the test may become more reliable and valid.

One of the biggest limitations of this study is its sample size. The size is rather small $(N=72)$, but when broken down into the sub-categories based on condition group, ethnicity, and national affiliation, the size of the sample becomes a concern. Because of the sizes of the groups when combined, which range from $n=2$ to $n=51$, the probability of the results being adequately generalizable is quite small. Though random assignment of participants to one of the two condition groups alleviates some of the concerns regarding having a small sample, future research on this topic should aim to recruit a larger number of participants from across Canada to ensure greater external validity on a national scale. In particular, more PoC $(n=21)$ and more participants who did not identify with Canada ( $n=$ 10) are needed in order to have a more balanced sample. In addition, everyone in the sample is attaining some kind of formal post-secondary education. Had the sample included adults who were not attending university, then the results may have more external validity and be more generalizable. The issue of education could influence perceived racism in Canada. Most post-secondary students are more inclined to keep up with national and local news in addition to being exposed to Canadian history, present circumstances, and are being taught to think critically and see the world through certain lenses (i.e., a racial lens) which might increase one's ability to perceive micro-aggressions. The potential effect of education on the outcomes of the study is shown in part through the sample in Group 1. Those who read the vignette and completed the questionnaire were also asked about whether they had heard about the Michael Brown case prior to completing the study. Twenty-five (25) out of the 32 participants in Group 1 had previously heard of the Michael Brown case, which could potentially be a confound and might be the result of only testing university students.

\section{Potential Next Steps}

Firstly, future research should address the limitations of this study. The results of this study lead to multiple other research questions to be explored regarding potential causes and relationships between variables. For example, future studies on this topic could explore how the proximity between America and Canada, as well as the transfer of media from American to Canadian audiences, affects how PoC perceive racism in Canada based on what they view from America. In addition, future studies could explore the use of different media types (e.g., radio, television, movies, advertisements) and utilize different levels of media (e.g., ambiguous, specifically Canadian, specifically American, etc.,) to explore the relationship between how racism is perceived in the in-group versus the out-group and whether the media types mediate this effect. Whether group identification varies depending on the individual's political ideology, versus that of the federal or provincial government, should also be examined to give more insight into potential limitations of social identity theory. Lastly, another research question that may be explored is the increasing dependence on the internet and globalization, and whether perceived differences between groups (i.e. perceptual accentuation of self-categorization theory) are influenced by these factors, and whether this affects how individuals compare their national groups to others. 


\section{References}

Atkins, R. (2014). Instruments measuring perceived racism/racial discrimination: Review and critique of factor analytic techniques. Health \& Human Services Public Access, 44(4), 711-734.

Bentley, S. V., Greenaway, K. H., \& Haslam, S. A. (2017). Cognition in context: Social inclusion attenuates the psychological boundary between self and other. Journal of Experimental Social Psychology, 73, 42-49. Retrieved from: http://dx.doi.org/10.1016/j.jesp.2017.06.008.

Canadian Council for Refugees. (2018). 2017 Immigration levels - Comments. Retrieved from http://ccrweb.ca/en/2017-immigration-levelscomments.

Druckman, D. (1994). Nationalism, patriotism, and group loyalty: A social psychological perspective. Mershon International Studies Review, 38, 43-68.

Esses, V. M., Dovidio, J. F., Jackson, L. M., \& Armstrong, T. L. (2001). The immigration dilemma: The role of perceived group competition, ethnic prejudice, and national identity. Journal of Social Issues, 57(3), 389-412.

Ferguson unrest: From shooting to nationwide protests. (August 10, 2015). BBC News. Retrieved from: http://www.bbc.com/news/world-us-canada30193354 .

Gulliver, T. (2017). Canada the redeemer and denials of racism. Critical Discourse Studies, 15(1), 68-86. Retrieved from: https://doi.org/10.1080/17405904.2017.1360192.

Mummendey, A., Klink, A., \& Brown, R. (2001). Nationalism and patriotism: National identification and outgroup rejection. British Journal of Social Psychology, 40, 159-172.

Tajfel, H. (1978). Differentiation between social groups: Studies in the social psychology of intergroup relations. London: Academic Press.

United Nations. (2012). Report of the Committee on the Elimination of Racial Discrimination. New York, NY.
U. S. Department of Homeland Security. (2018). Legal immigration and adjustment of status report fiscal year 2017, quarter 4. Retrieved from https://www.dhs.gov/immigrationstatistics/special-reports/legal-immigration.

Vala, J. (2009). Editorial: Expressions of "new" racism. Psychology Press, 44(1), 1-3. Retrieved from: https://doi.org/10.1080/00207590802057548.

Van Lange, P. A. M., Kruglanski, A. W., \& Higgins, E. T. (2011). Handbook of theories of social psychology: Volume two. Thousand Oaks, CA: SAGE Publications.

Waters, R. P. (2015). A march from Selma to Canada: Canada and the transnational civil rights movement (Doctoral dissertation). Retrieved from McMaster University Libraries.

Wendt, S. (2009). Transnational perspectives on the history of racism in North America. American Studies, 54(3), 473-498. 


\section{Appendix A}

Consent

\section{Emily Wiebe}

Undergraduate Student, College of Arts and Science

University of Saskatchewan

Email: emw981@usask.ca

\section{Jason Disano}

Director of Social Sciences Research Laboratories, College of Arts and Science

University of Saskatchewan

E-mail: jason.disano@usask.ca

Phone: (306) 966-7546

The primary purpose of this study is to gather data regarding perceptions of Canada and America from the point of view of people currently living in Canada. We are interested in learning about the comparisons that are drawn between America and Canada in terms of overall life satisfaction, perceived racism, and perceived diversity and acceptance. We invite you to tell us your opinions.

This 10-minute survey is hosted by Voxco, a Canadian-owned and managed company whose data is securely stored in Canada. Your data will be kept completely confidential and no personally identifying information will be linked to your data.

For any questions or concerns or to obtain results from the study, please contact the student researcher or supervisor using the information at the top of this page. This research project has been approved on ethical grounds by the University of Saskatchewan Research Ethics Board, and has indicated that there are no foreseeable risks. Any questions regarding your rights as a participant may be addressed to that committee through the Research Ethics Office ethics.office@usask.ca; (306) 966-2975. Out of town participants may call toll free (888) 966-2975.

In order to complete this survey, you may be required to answer certain questions; however, you are never obligated to respond and you may withdraw from the survey at any time by closing your internet browser. Participation is strictly voluntary.

By selecting next and completing this questionnaire, your free and informed consent is implied and indicates that you understand the above conditions to participate in this study.

Please consider printing this page for your records. 


\section{DESCRIPTION}

On the following screen, you'll be asked to read and review a media article from a United States news source STLtoday. Please be sure to read through carefully before continuing.

\section{CHECK}

\section{Ferguson: As It Unfolded (source: STLtoday)}

At 12:02 p.m. on Aug. 9, 2014, Ferguson police Officer Darren Wilson radioed that he was stopping two people at the Canfield Green apartment complex in Ferguson. Less than 90 seconds later, 18-year-old Michael Brown was dead in the street. His body remained there for four hours as the crowd grew. Witnesses who went public said Brown was trying to surrender when he was killed. Wilson, through his police superiors and others, said Brown initiated the violence.

People took to the streets immediately after the shooting of Michael Brown. "Hands up. Don't shoot," they chanted, echoing witness statements that Brown was trying to surrender when he was shot. (Police Officer Darren Wilson and some witnesses said Brown charged at Wilson.) The day after the shooting, violence broke out and the QuikTrip was looted and burned. In the days and weeks afterward, gatherings during the day were peaceful. At night, things got tense.

Key details of police Officer Darren Wilson's encounter with Michael Brown did not emerge for weeks. The private autopsy results, released early on, showed that Brown was struck by six rounds. The county autopsy, obtained by the Post-Dispatch weeks later, showed a close-range wound to Brown's hand. The investigation took months, but scant information was offered publicly. The newspaper obtained county dispatch records and conducted multiple interviews to figure out why Brown's body was left on the street for so many hours. The public records request for radio calls resulted in a story showing the entire encounter lasted about 90 seconds.

Scrutiny of police tactics extends far beyond the tick-tock of events on Aug. 9. Why was so little information shared? Why did police respond to protesters with dogs, military vehicles and sniper rifles? In the days that followed the shooting, the images of police dressed in full riot gear, tossing tear gas as they clashed with protesters triggered a nationwide debate about the militarization of law enforcement. That conversation has spilled over to other areas, such as the use of body cameras, the lack of diversity in the ranks, a shortage of data on fatal police shootings and calls for consolidating local departments.

"You've got issues in this city," the Rev. Al Sharpton told a standing-room-only crowd three days after the shooting. The issues raised in Ferguson include police killings of black men, racial 
disparity in police stops and searches, courts that many say prey on poor people, and dysfunctional schools in black neighborhoods. Jesse Jackson protested. Bernice King worked with students to promote nonviolence. And a new generation stepped up to lead a new movement.

The question of whether to criminally indict police Officer Darren Wilson for Brown's shooting dominated the political conversation from the start. And from the beginning, the process itself was a source of dispute. Some wanted St. Louis County Prosecuting Attorney Robert McCulloch - whom they felt could not be impartial for personal reasons - to step aside. Instead, McCulloch decided to present all the evidence to a grand jury and let the jurors decide without a recommendation from his office. On Nov. 24, the panel voted to not indict. But questions about that decision - and more generally, the unusual process that led to it - continue, as those on both sides pore through thousands of pages of grand jury documents.

The Michael Brown shooting has intensified the public's interest in other fatal shootings by police. Just 11 days after Brown's death, St. Louis police killed Kajieme Powell, who was brandishing a knife. On Oct. 9, VonDerrit Myers was shot and killed by an off-duty police officer in St. Louis. Police say Myers fired first. The Myers killing created a second protest site, with crowds gathering in the Shaw neighborhood and along South Grand Boulevard, where several businesses were damaged. The fatal shooting of 18-year-old Antonio Martin on Dec. 23 in Berkeley reignited tension between protesters and police.

Almost immediately, the Michael Brown shooting and its aftermath spawned conversations and meetings about how the community should respond. Events large and small were held in churches and government buildings. Thousands of area residents turned out to talk about what changes were needed. Later, Missouri Gov. Jay Nixon formed the 16-member Ferguson Commission to seek a way forward for the community. Most residents know that there are no easy answers and the efforts continue.

I I have read and understood this article

TIMER

Satisfaction 1

Read the statements below carefully. Please indicate how much you agree with each statement by selecting the bubble under the appropriate response. Please note that all responses will remain confidential and that you may choose to leave any questions that make you uncomfortable unanswered. 


\begin{tabular}{|c|c|c|c|c|c|c|c|}
\hline & $\begin{array}{l}\text { Strongly } \\
\text { disagree }\end{array}$ & Disagree & $\begin{array}{l}\text { Slightly } \\
\text { disagree }\end{array}$ & $\begin{array}{l}\text { Neither } \\
\text { agree nor } \\
\text { disagree }\end{array}$ & $\begin{array}{l}\text { Slightly } \\
\text { agree }\end{array}$ & Agree & $\begin{array}{l}\text { Strongly } \\
\text { agree }\end{array}$ \\
\hline $\begin{array}{l}\text { I like living in } \\
\text { Canada. }\end{array}$ & 0 & 0 & 0 & 0 & 0 & 0 & ○ \\
\hline $\begin{array}{l}\text { I think Canada } \\
\text { is a good place } \\
\text { to live. }\end{array}$ & O & O & O & o & 0 & O & O \\
\hline $\begin{array}{l}\text { Overall, my } \\
\text { time in Canada } \\
\text { has been } \\
\text { pleasant. }\end{array}$ & O & O & O & o & o & o & O \\
\hline $\begin{array}{l}\text { My view of } \\
\text { Canada is } \\
\text { generally } \\
\text { positive. }\end{array}$ & O & O & o & o & O & O & O \\
\hline $\begin{array}{l}\text { I view Canada } \\
\text { in a negative } \\
\text { light }\end{array}$ & O & O & O & o & O & O & 0 \\
\hline $\begin{array}{l}\text { My overall } \\
\text { experiences } \\
\text { living in } \\
\text { Canada have } \\
\text { been bad. }\end{array}$ & O & O & O & 0 & O & ○ & ○ \\
\hline $\begin{array}{l}\text { Life in Canada } \\
\text { is great. }\end{array}$ & O & O & 0 & O & O & O & O \\
\hline $\begin{array}{l}\text { Canada is one } \\
\text { of the best } \\
\text { countries in the } \\
\text { world. }\end{array}$ & O & O & o & o & O & o & o \\
\hline $\begin{array}{l}\text { My time in } \\
\text { Canada has } \\
\text { been } \\
\text { unsatisfactory. }\end{array}$ & O & O & o & o & O & 0 & o \\
\hline $\begin{array}{l}\text { I wish I lived } \\
\text { somewhere } \\
\text { else. }\end{array}$ & 0 & 0 & O & 0 & 0 & 0 & 0 \\
\hline
\end{tabular}

\section{Diversity1}


Read the statements below carefully. Please indicate how much you agree with each statement by selecting the bubble under the appropriate response. Please note that all responses will remain confidential and that you may choose to leave any questions that make you uncomfortable unanswered.

\begin{tabular}{|c|c|c|c|c|c|c|c|}
\hline & $\begin{array}{l}\text { Strongly } \\
\text { disagree }\end{array}$ & Disagree & $\begin{array}{l}\text { Slightly } \\
\text { disagree }\end{array}$ & $\begin{array}{l}\text { Neither } \\
\text { agree nor } \\
\text { disagree }\end{array}$ & $\begin{array}{l}\text { Slightly } \\
\text { agree }\end{array}$ & Agree & $\begin{array}{l}\text { Strongly } \\
\text { agree }\end{array}$ \\
\hline $\begin{array}{l}\text { Canada is } \\
\text { home to many } \\
\text { people from } \\
\text { lots of } \\
\text { different } \\
\text { backgrounds. }\end{array}$ & 0 & 0 & 0 & 0 & 0 & 0 & 0 \\
\hline $\begin{array}{l}\text { Immigrants } \\
\text { should come } \\
\text { to Canada. }\end{array}$ & 0 & 0 & 0 & 0 & 0 & 0 & 0 \\
\hline $\begin{array}{l}\text { Canadians are } \\
\text { accepting } \\
\text { of everyone. }\end{array}$ & 0 & 0 & 0 & 0 & 0 & 0 & 0 \\
\hline $\begin{array}{l}\text { Immigrants } \\
\text { most likely } \\
\text { feel welcomed } \\
\text { when they } \\
\text { come to } \\
\text { Canada. }\end{array}$ & 0 & 0 & 0 & 0 & 0 & 0 & 0 \\
\hline $\begin{array}{l}\text { Canadians } \\
\text { hate } \\
\text { foreigners. }\end{array}$ & 0 & 0 & 0 & 0 & 0 & 0 & 0 \\
\hline $\begin{array}{l}\text { All ethnic } \\
\text { groups are } \\
\text { equally } \\
\text { accepted in } \\
\text { Canadian } \\
\text { society. }\end{array}$ & 0 & 0 & 0 & 0 & 0 & 0 & 0 \\
\hline $\begin{array}{l}\text { I feel that I am } \\
\text { an } \\
\text { accepted } \\
\text { member of } \\
\text { Canadian } \\
\text { society. }\end{array}$ & 0 & 0 & 0 & 0 & 0 & 0 & 0 \\
\hline $\begin{array}{l}\text { Most people } \\
\text { living in }\end{array}$ & & & & & & & \\
\hline
\end{tabular}




\begin{tabular}{|l|c|c|c|c|c|c|c|}
\hline $\begin{array}{l}\text { Canada are not } \\
\text { of } \\
\text { European } \\
\text { descent. }\end{array}$ & 0 & 0 & 0 & 0 & 0 & 0 & 0 \\
\hline $\begin{array}{l}\text { Indigenous } \\
\text { people are } \\
\text { treated just like } \\
\text { everyone } \\
\text { else in Canada. }\end{array}$ & 0 & 0 & 0 & 0 & 0 & 0 & 0 \\
\hline $\begin{array}{l}\text { Anyone is } \\
\text { welcome to } \\
\text { move to } \\
\text { Canada. }\end{array}$ & 0 & 0 & 0 & 0 & 0 & 0 & 0 \\
\hline
\end{tabular}

\section{Racism1}

Read the statements below carefully. Please indicate how much you agree with each statement by selecting the bubble under the appropriate response. Please note that all responses will remain confidential and that you may choose to leave any questions that make you uncomfortable unanswered.

\begin{tabular}{|c|c|c|c|c|c|c|c|}
\hline & $\begin{array}{l}\text { Strongly } \\
\text { disagree }\end{array}$ & Disagree & $\begin{array}{l}\text { Slightly } \\
\text { disagree }\end{array}$ & $\begin{array}{l}\text { Neither } \\
\text { agree nor } \\
\text { disagree }\end{array}$ & $\begin{array}{l}\text { Slightly } \\
\text { agree }\end{array}$ & Agree & $\begin{array}{l}\text { Strongly } \\
\text { agree }\end{array}$ \\
\hline $\begin{array}{l}\text { I hear } \\
\text { derogatory } \\
\text { terms directed } \\
\text { toward } \\
\text { someone } \\
\text { because of } \\
\text { their } \\
\text { skin color. }\end{array}$ & 0 & 0 & 0 & 0 & 0 & 0 & 0 \\
\hline $\begin{array}{l}\text { I see violent } \\
\text { acts against } \\
\text { people } \\
\text { because of } \\
\text { their skin } \\
\text { color. }\end{array}$ & 0 & 0 & 0 & 0 & 0 & O & 0 \\
\hline $\begin{array}{l}\text { I see } \\
\text { stereotypical } \\
\text { representations } \\
\text { of certain } \\
\text { ethnic } \\
\text { groups on } \\
\text { Canadian TV } \\
\text { shows. }\end{array}$ & O & 0 & 0 & 0 & O & O & O \\
\hline
\end{tabular}




\begin{tabular}{|c|c|c|c|c|c|c|c|}
\hline $\begin{array}{l}\text { I see how } \\
\text { racial } \\
\text { discrimination } \\
\text { impacts some } \\
\text { Canadian } \\
\text { citizens. }\end{array}$ & 0 & 0 & 0 & 0 & 0 & 0 & 0 \\
\hline $\begin{array}{l}\text { I think } \\
\text { Indigenous } \\
\text { communities } \\
\text { should be } \\
\text { treated with } \\
\text { more } \\
\text { respect }\end{array}$ & 0 & 0 & 0 & 0 & 0 & 0 & $\circ$ \\
\hline $\begin{array}{l}\text { I think that } \\
\text { Canadian law } \\
\text { enforcement } \\
\text { handles cases } \\
\text { differently } \\
\text { depending on } \\
\text { the } \\
\text { victim's skin } \\
\text { color. }\end{array}$ & 0 & 0 & 0 & 0 & 0 & 0 & 0 \\
\hline $\begin{array}{l}\text { I think that } \\
\text { Canadian law } \\
\text { enforcement } \\
\text { handles cases } \\
\text { differently } \\
\text { depending on } \\
\text { the } \\
\text { perpetrator's } \\
\text { skin color. }\end{array}$ & 0 & 0 & 0 & 0 & 0 & 0 & 0 \\
\hline $\begin{array}{l}\text { I think that } \\
\text { some people } \\
\text { don't } \\
\text { get the same } \\
\text { amount of } \\
\text { opportunities } \\
\text { as me because } \\
\text { of } \\
\text { their skin } \\
\text { color. }\end{array}$ & 0 & 0 & 0 & 0 & 0 & 0 & 0 \\
\hline $\begin{array}{l}\text { I think that } \\
\text { certain ethnic } \\
\text { groups } \\
\text { are treated } \\
\text { differently } \\
\text { because of } \\
\text { their skin } \\
\text { color. }\end{array}$ & 0 & 0 & 0 & 0 & 0 & 0 & 0 \\
\hline $\begin{array}{l}\text { I think I don't } \\
\text { have the same } \\
\text { amount of } \\
\text { opportunities } \\
\text { as }\end{array}$ & 0 & 0 & 0 & 0 & 0 & 0 & 0 \\
\hline
\end{tabular}




\begin{tabular}{|l|l|l|l|l|l|l|l|}
\hline $\begin{array}{l}\text { others because } \\
\text { of my skin } \\
\text { color. }\end{array}$ & & & & & & & \\
\hline
\end{tabular}

\section{Comparison 1}

Read the statements below carefully. Please indicate how much you agree with each statement by selecting the bubble under the appropriate response. Please note that all responses will remain confidential and that you may choose to leave any questions that make you uncomfortable unanswered.

\begin{tabular}{|c|c|c|c|c|c|c|c|}
\hline & $\begin{array}{l}\text { Strongly } \\
\text { disagree }\end{array}$ & Disagree & $\begin{array}{l}\text { Slightly } \\
\text { disagree }\end{array}$ & $\begin{array}{l}\text { Neither } \\
\text { agree nor } \\
\text { disagree }\end{array}$ & $\begin{array}{l}\text { Slightly } \\
\text { agree }\end{array}$ & Agree & $\begin{array}{l}\text { Strongly } \\
\text { agree }\end{array}$ \\
\hline $\begin{array}{l}\text { I think that } \\
\text { Canada is a } \\
\text { better } \\
\text { country than } \\
\text { the } \\
\text { USA. }\end{array}$ & 0 & 0 & 0 & 0 & O & 0 & 0 \\
\hline $\begin{array}{l}\text { Racism is } \\
\text { experienced } \\
\text { more } \\
\text { in the USA } \\
\text { than in } \\
\text { Canada. }\end{array}$ & 0 & 0 & 0 & 0 & 0 & O & O \\
\hline $\begin{array}{l}\text { Immigrants } \\
\text { and } \\
\text { refugees are } \\
\text { safer } \\
\text { in Canada than } \\
\text { the } \\
\text { USA. }\end{array}$ & 0 & 0 & 0 & 0 & 0 & 0 & 0 \\
\hline $\begin{array}{l}\text { The USA and } \\
\text { Canada have } \\
\text { similar laws in } \\
\text { regards to } \\
\text { handling } \\
\text { hate crimes. }\end{array}$ & 0 & 0 & 0 & 0 & 0 & 0 & 0 \\
\hline $\begin{array}{l}\text { The USA and } \\
\text { Canada are } \\
\text { equal } \\
\text { in terms of the } \\
\text { severity of } \\
\text { racism } \\
\text { experienced by }\end{array}$ & 0 & 0 & 0 & 0 & 0 & 0 & O \\
\hline
\end{tabular}




\begin{tabular}{|c|c|c|c|c|c|c|c|}
\hline $\begin{array}{l}\text { a } \\
\text { marginalized } \\
\text { group. }\end{array}$ & & & & & & & \\
\hline $\begin{array}{l}\text { Everyone has } \\
\text { equal } \\
\text { opportunities } \\
\text { in } \\
\text { the USA, but } \\
\text { not in } \\
\text { Canada. }\end{array}$ & 0 & 0 & 0 & 0 & 0 & 0 & 0 \\
\hline $\begin{array}{l}\text { Everyone has } \\
\text { equal } \\
\text { opportunities } \\
\text { in } \\
\text { Canada, but } \\
\text { not } \\
\text { the USA. }\end{array}$ & 0 & 0 & 0 & 0 & 0 & 0 & 0 \\
\hline $\begin{array}{l}\text { I think the } \\
\text { USA is } \\
\text { a better place } \\
\text { to } \\
\text { live than } \\
\text { Canada. }\end{array}$ & 0 & 0 & 0 & 0 & 0 & 0 & 0 \\
\hline $\begin{array}{l}\text { Immigrants } \\
\text { and } \\
\text { refugees } \\
\text { should go } \\
\text { to the USA, not } \\
\text { Canada. }\end{array}$ & 0 & 0 & 0 & 0 & 0 & 0 & 0 \\
\hline $\begin{array}{l}\text { Acts of racism } \\
\text { occur at a } \\
\text { higher } \\
\text { rate in Canada } \\
\text { than in the } \\
\text { USA. }\end{array}$ & 0 & 0 & 0 & 0 & 0 & 0 & 0 \\
\hline
\end{tabular}

Ethnicity

What ethnicity do you identify with?

- Caucasian

- East Asian (e.g., Chinese, Japanese, Korean)

- Black (e.g., African, African American/Canadian, Carribean)

- Southeast Asian (e.g., Burmese, Cambodian, Filipino, Thai, Vietnamese)

- West Asian (e.g., Arabian, Armenian, Iranian, Israeli, Syrian, etc.)

- South Asian (e.g., Indian, Pakistani, Sri Lankan, Bangladeshi)

- Hispanic

- Indigenous (e.g., First Nations, Metis, Inuit) 
- Mixed origin, please specify:

- If you identify differently than the options listed above, please specify:

\section{Countryofbirth}

What country were you born in?

Home

What ONE country would you consider to be home to you?

Mosttime

In which country have you spent most of your life?

Timeincanada

How long have you lived in Canada?
- Less than a year
- 1-4 years
- 5-9 years
○ $10+$ years

Birthday

What is your date of birth (DD/MM/YYYY)?

○ N/A

- Refusal

- Do not know

Michaelbrown

Had you heard about the Michael Brown case prior to participating in this study?

- Yes

- No

Debrief 
The purpose of this survey is to explore whether the classification of Canada and Canadians from their perspective differs as a function of exposure to American news and media. More specifically, the study aims to identify whether perceptions of racism in Canada are influenced by levels of American television, politics, news, or other media types versus levels of Canadian media sources. Our research predicts that exposure to American media will cause Canadians to have greater levels of national pride and higher perceived diversity/acceptance, and lower scores in regards to prevalence of racism in Canada. Furthermore, we predict to see Canadians score Canada better in comparison to America in general, but for that discrepancy to be widened when participants are exposed to American media. In addition, we predict that non-white Canadians will nt be impacted by American media on the aforementioned categories. Your participation helps us to learn and understand the ways that national identification and media exposure influence perceptions of inequality.

If you have any questions about the survey or would like to receive a summary of the research results, please contact Emily Wiebe (emw981@usask.ca), Undergraduate Student, or Mr. Jason Disano (jason.disano@usask.ca), Director of the Social Sciences Research Laboratory. 
$420 \mathrm{aros}$

Qunstsnsain

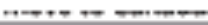

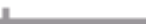

Raclsm1

Read the statements below carefully. Please indlcate how frequently you experience/withess each statement by selecting the bubble under the appropitate response. Please note that all responses will remain confidential and that you may choose to leave any questions that make you uncomfortable unanswered.

\begin{tabular}{|c|c|c|c|c|c|}
\hline & Newer & Rarely & Sometimes & Often & Always \\
\hline $\begin{array}{l}\text { I hear derogatory terms directed } \\
\text { toward someone because of their } \\
\text { stin color. }\end{array}$ & 0 & 0 & 0 & 0 & 0 \\
\hline $\begin{array}{l}\text { I see volent acts against people } \\
\text { because of their skin color. }\end{array}$ & 0 & 0 & 0 & 0 & 0 \\
\hline $\begin{array}{l}\text { I see stereotypical } \\
\text { representations of certain ethnic } \\
\text { groups on Canadian TV shows. }\end{array}$ & 0 & 0 & 0 & 0 & 0 \\
\hline $\begin{array}{l}\text { I see how racial discrimination } \\
\text { impacts some Canadian citizens. }\end{array}$ & 0 & 0 & 0 & 0 & 0 \\
\hline $\begin{array}{l}\text { I think Indigenous communities } \\
\text { should be treated with more } \\
\text { respect. }\end{array}$ & 0 & 0 & 0 & 0 & 0 \\
\hline $\begin{array}{l}\text { I think that Canadian law } \\
\text { entorcement handles cases } \\
\text { differendly depending on the } \\
\text { victim's skin color. }\end{array}$ & 0 & 0 & 0 & 0 & 0 \\
\hline $\begin{array}{l}\text { I think that Canadian law } \\
\text { enforcememt handles cases } \\
\text { differendy depending on the } \\
\text { perpetrator's skin color. }\end{array}$ & 0 & 0 & 0 & 0 & 0 \\
\hline $\begin{array}{l}\text { I think that some people don't } \\
\text { get the same amount of } \\
\text { opportunities as me because of } \\
\text { their skin color. }\end{array}$ & 0 & 0 & 0 & 0 & 0 \\
\hline $\begin{array}{l}\text { I think that certain ethnic groups } \\
\text { are treated differently because of } \\
\text { their skin color. }\end{array}$ & 0 & 0 & 0 & 0 & 0 \\
\hline $\begin{array}{l}\text { I think I dorrt have the same } \\
\text { amount of opportunities as } \\
\text { others because of my skin color. }\end{array}$ & 0 & 0 & 0 & 0 & 0 \\
\hline
\end{tabular}

\section{Comparison1}

Read the statements below carefully. Please indlcate how much you agree with each statement by selecting the bubole under the approprlate response. Please note that all responses wil rentiln confidential and that you may choose to leave any questions that make you uncomfortable unanswered.

\begin{tabular}{|c|c|c|c|c|c|c|c|}
\hline & $\begin{array}{l}\text { Strongly } \\
\text { disagree }\end{array}$ & Disagree & $\begin{array}{l}\text { slightly } \\
\text { disagree }\end{array}$ & $\begin{array}{l}\text { Neither } \\
\text { agree nor } \\
\text { disagree }\end{array}$ & $\begin{array}{c}\text { Stightly } \\
\text { agree }\end{array}$ & Agree & $\begin{array}{c}\text { Strongly } \\
\text { agree }\end{array}$ \\
\hline $\begin{array}{l}\text { I think that } \\
\text { Canada is a better } \\
\text { country than the } \\
\text { USA }\end{array}$ & 0 & 0 & 0 & 0 & 0 & 0 & 0 \\
\hline $\begin{array}{c}\text { Racism is } \\
\text { experienced more } \\
\text { in the USA than in } \\
\text { Canada. }\end{array}$ & 0 & 0 & 0 & 0 & 0 & $\overline{0}$ & 0 \\
\hline $\begin{array}{l}\text { Immigrants and } \\
\text { refugees are safer } \\
\text { in Canada than the } \\
\text { USA. }\end{array}$ & 0 & 0 & 0 & 0 & 0 & 0 & 0 \\
\hline
\end{tabular}




\begin{tabular}{|c|c|c|c|c|c|c|c|}
\hline $\begin{array}{l}\text { The USA and } \\
\text { Canada have } \\
\text { similar laws in } \\
\text { regards to handing } \\
\text { hate crimes. }\end{array}$ & 0 & 0 & 0 & 0 & 0 & 0 & 0 \\
\hline $\begin{array}{l}\text { The USA and } \\
\text { Canada are equal } \\
\text { in terms of the } \\
\text { severity of racism } \\
\text { experienced by a } \\
\text { marginalized } \\
\text { group. }\end{array}$ & 0 & 0 & 0 & 0 & 0 & 0 & 0 \\
\hline $\begin{array}{l}\text { Everyone has } \\
\text { equal } \\
\text { opportunities in } \\
\text { the USA but not in } \\
\text { Canada. }\end{array}$ & 0 & 0 & 0 & 0 & 0 & 0 & 0 \\
\hline $\begin{array}{l}\text { Everyone has } \\
\text { equal } \\
\text { opportunities in } \\
\text { Canada, but not } \\
\text { the USA }\end{array}$ & 0 & 0 & 0 & 0 & 0 & 0 & 0 \\
\hline $\begin{array}{l}\text { I think the USA is } \\
\text { a better place to } \\
\text { live than Canada. }\end{array}$ & 0 & 0 & 0 & 0 & 0 & 0 & 0 \\
\hline $\begin{array}{l}\text { Immigrants and } \\
\text { refugees should go } \\
\text { to the USA not } \\
\text { Canada. }\end{array}$ & 0 & 0 & 0 & 0 & 0 & 0 & 0 \\
\hline $\begin{array}{l}\text { Acts of racism } \\
\text { occur at a higher } \\
\text { rate in Canada } \\
\text { than in the USA. }\end{array}$ & 0 & 0 & 0 & 0 & 0 & 0 & 0 \\
\hline
\end{tabular}

ethnichty

\section{What ethnicity do you identry with?}
- Caucaslan
- East Aslan (e.g. Chinese, Japanese, Korean)
- Black (e.g., Afilican, Amican American/Canadian, Cartbbean)
- Southeast Aslan (eg., Burmese, Cambodlan, Filpino, Thal, Vetnamese)
- West Aslan (e.g., Arablan, Armenlan, Iranlan, istael, Syrlan, etc.)
- South Aslan (.e.g. Indlan, Pakistanl, Srl Lankan, Bangladesh)
o Hispanic
o Indlgenous (e.g., First Nations, Metis, Inuit)
- Mbed origln, please specity:

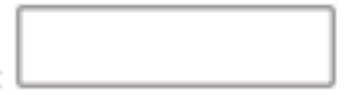

o If you identily differently than the options Ilsted above, please specily:

\section{countryofbirth}


4002013

Questonsedic

What country were you bom in?

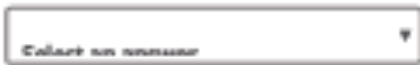

home

What ONE country would you consider to be home to you?

Select an arswer.-

mosttime

In which country have you spent most of your life?

Select an answer.-

timelncanada

How long have you Ilved in Canada?
- Less than a year
o 1-4 years
o 5 -9 years
o $10+$ years

birthday

What is your date of birth (DDMMMYrY)?
N/A
- Refusal
- Do not know

michaelbrown

Had you heard about the Mchael Brown case prior to participating in this study?

Ye6

No

Debrlef

Thank you for your particlpation in this survey.

The purpose of this survey is to explore whether the classiltcation of Canada and Canadians from their perspective difrers as a function of exposure to American news and media. Mare specincally, the study alms to identify whether perceptlons of racism in Canada are influenced by levels of American television, pollics, news, or other medla types versub levels of Canadlan medla sources. Our rebearch predicts that exposure to American medla will cause Canadians to have greater levels of national pride and higher percelved dlverstylacceptance, and lower scores in regardis to 
4202018

Cumbiontaire

prevalence of ractsm in Canada. Furthermore; we predlct to see Carladians score Canada better in comparison to America in genera, but for that discrepancy to be widened when participants are exposed to American medla. in addition, we predict that non-white Canadlans wil not be impacted by American medla on the aforementioned categorles. Your participation helps us to leam and understand the ways that national identfincation and medla exposure infuence perceptions of inequality.

If you have any questions about the survey or would ilke to recelve a summary of the research results, please contact Enly Webe (ema981 gmal.usask.ca), Undergraduate Student or Mr. Jason Disano (jason.disanogi Usask.ca), Director of the Soclal Sdences Research Laboratory. 
How American Media Affects Perceived Racism in Canada (Wiebe)

University of Saskatchewan Undergraduate Research Journal 